\title{
Evaluation of Heavy Metal Pollution from Vehicular Exhausts in Soils along a Highway, Southwestern Nigeria
}

\author{
Kaseem Olusola Ayinde ${ }^{1}$, Soladoye Mohammed Omotosho ${ }^{1}$, Olubukunola \\ Oluwole Oyesiku ${ }^{1}$, Roseline Tolulope Feyisola ${ }^{1}$, Olubola Abiola ${ }^{2}$, Adeshina \\ Luqman Adisa ${ }^{3}$
}

\author{
${ }^{1}$ Plant Science Department, Olabisi Onabanjo University, Ago-Iwoye, Ogun State, Nigeria \\ ${ }^{2}$ Department of Applied Geophysics, Federal University of Technology, Akure, Nigeria \\ ${ }^{3}$ Department of Applied Geology, Federal University of Technology, Akure, Nigeria
}

Received: 10 Oct 2020; Received in revised form: 9 Nov 2020; Accepted: 9 Nov 2020; Available online: 13 Nov 2020

\begin{abstract}
The Lagos-Ibadan Expressway is the busiest inter-state route in Nigeria and one of the largest road networks in Africa. It handles more than 250,000 PCUs (Passenger Car Units) daily. Amount of metal emissions being released daily from vehicles plying this road into the environment (air, soil, plant and water) is great! This study evaluated heavy metal composition in soils resulting from exhausts pollution from vehicular movement along Lagos-Ibadan Expressway. A total of two hundred and seventysix soil samples were collected at 5, 15 and $25 \mathrm{~m}$ away from the edge of the road. The soil samples were collected with hand auger from the surface to a depth of $10 \mathrm{~cm}$ during both dry and wet seasons. Heavy metal concentrations were determined using Atomic Absorption Spectrophotometer (AAS). The heavy metal concentrations found in sampled soil during dry season in $\mathrm{mg}_{\mathrm{kg}} \mathrm{kg}^{-1}$ along the study sites revealed the following, $\mathrm{Zn}$ (558.03, 21.98), $\mathrm{Pb}$ (130.96, 3.64), Cr (24.08, 1.09), Cu (97.43, 4.41) and during wet season $\mathrm{Zn}$ (532.51, 5.72), $\mathrm{Pb}$ (120.52, 1.85), $\mathrm{Cu}$ (79.90, 1.05), $\mathrm{Cr}$ (19.82, 0.22). The results indicated a general reduction in heavy metal concentrations in the soil collected during rainy season, when compared with soil collected during dry season. Index of geo-accumulation $\left(I_{g e o}\right)$ of sampled soils revealed that contamination ranged from moderate to extreme in all the study locations during dry and wet seasons. Potential ecological risk Index (PERI) of the individual location in the study area ranged from 4.38 to 146.84. However, the total PERI of study area was 1136, which indicated that Lagos - Ibadan Expressway is generally polluted with heavy metals. $\mathrm{Fe}, \mathrm{Mn}, \mathrm{Zn}, \mathrm{Pb}, \mathrm{Cu}$ and $\mathrm{Cr}$ are the major heavy metal pollutants found in the soils during dry and wet seasons. The source of these heavy metals being vehicular exhausts emissions along Lagos - Ibadan Expressway.
\end{abstract}

Keywords - Contamination, heavy metals, Potential Ecological Risk Index, soil, vehicular exhausts.

\section{INTRODUCTION}

In many parts of the world today, vehicular exhaust emissions from heavy-duty trucks and other vehicles constitute one of the sources of plant and soil pollution (Akbar et al., 2006). Olukanni and Adebiyi, (2012); Ezemokwe et al., (2017) and Fosu-Mensah et al., (2017) observed that heavy metals affect the ecosystem especially along major highways through these emissions. Soils along roadsides often contain high concentrations of heavy metals and other contaminants. These metals are released from fuel burning (either gasoline or diesel), wearing out of tires, leakage of oils, and corrosion of car metal parts (Dolan et. al., 2006; Olukanni and Adebiyi, 2012). The resultant effect has adversely affected plants, soil, water, air and animals including humans in many urban areas around the world.

Lagos-Ibadan Expressway is a major highway in southwestern Nigeria that links other parts of the country. Nigeria, like other developing countries and some developed countries, has a problem of roadside pollution. 
As Africa's most populous nation, Nigeria has its share of smog-filled cities, congested roads, aging vehicles, leaded fuel usage among others, which invariably resulted in large scale pollution of our highways by heavy metals through emissions from vehicle exhausts. The road under study (Lagos - Ibadan Expressway) is one of the busiest highways in Africa. It regularly witness vehicular traffic congestion since it was commissioned in 1978 and vehicular pollution has not been checked by environmental regulatory authorities, leading to elevated levels of pollution year in year out. The pollution level is critical and might be attributed to the poor economic situation of Nigerians. Large importation of old and fairly-used cars and poor vehicle maintenance culture cause increase in the emissions of dangerous substances through the exhaust pipes of vehicles. Large number of irreparable and decomposing car parts litter the road surfaces and roadsides. These expose the residents to serious health risks.

Little or no attention has been placed on metal contamination of the major roads in the country despite its direct contact with a greater part of the population. Poszyler-Adamska \& Czerniak (2007) considered vehicle exhausts as first line of source of heavy metal pollutants in any major highway. Simon et al. (2013) pointed to the role of traffic emissions in the pollution of Wien soil by $\mathrm{Cu}$, $\mathrm{Pb}$, and $\mathrm{Zn}$. These are the most important metal pollutants from heavy traffic exhaust owing to their presence in fuel as antiknock agent (Suzuki et al., 2009; Atayese et al., 2010). Hence, this present work deals with the evaluation of heavy metals pollution in soils along Lagos-Ibadan Expressway, south western Nigeria, from vehicular exhausts emissions. The objectives of the study are to determine the: (i) concentrations of the prevalent heavy metals in soils along Lagos - Ibadan Expressway from vehicular exhausts emissions; (ii) seasonal effects of heavy metals on soil along the highway; and (iii) level of pollution along Lagos-Ibadan expressway using Pollution Assessment Indices.

\section{MATERIALS AND METHODS}

\subsection{The study area}

The study was carried - out along Lagos-Ibadan expressway. The highway stretches from Ibadan $\left(07^{\circ} 19.647^{\prime} \mathrm{N}, 003^{\circ} 52.528^{\prime} \mathrm{E}, 170 \mathrm{~m}\right.$ a.s.l) through Ajanla Farms $\left(06^{\circ} 55.140^{\prime} \mathrm{N}, 003^{\circ} 38.174 \mathrm{E}\right.$, $58 \mathrm{~m}$ a.s.l) to 7 up Bus stop at the Lagos end $\left(06^{\circ} 35.976^{\prime} \mathrm{N}, 003^{\circ} 22.710^{\prime} \mathrm{E}, 30 \mathrm{~m}\right.$ a.s.1). It covers a distance of $115 \mathrm{~km}$.

The topography from Ibadan end of the road is high hills ranging from $58 \mathrm{~m}$ to $170 \mathrm{~m}$ above sea level (Fig. 1) and ISSN: 2456-1878 characterized by low lying lands with gentle slopes in the vicinity of Sagamu Interchange.

Geologically, Lagos-Ibadan expressway is partly underlain by the crystalline rocks of the Precambrian Basement Complex and partly by the sedimentary rocks of the Dahomey basin. The Dahomey basin is a West African Atlantic Margin basin which is made up of Tertiary to Recent and Creteceous sediments (Omotsola \& Adegoke, 1981; Obaje, 2009). Lying unconformably above the basement rocks is Abeokuta formation. This formation is overlain by Ewekoro formation which is in turn overlain by the Benin formation (Coastal Plain Sands).

\subsection{Sampling Design}

The area sampled covered a distance of $115 \mathrm{~km}$ from Lagos end to Old Tollgate in Ibadan. Sampling started from 7up Bus - stop in Lagos through Ajanla Farms to Tollgate in Ibadan (Table 1). Soil samples were collected at intervals of $5 \mathrm{~km}$ in a zigzag manner across the expressway (Fig. 2). The samples were collected using hand auger from the surface to a depth of $10 \mathrm{~cm}$. At each location, three subsamples were taken at $5 \mathrm{~m}, 15 \mathrm{~m}$ and $25 \mathrm{~m}$ away from the edge of the road (Fig. 3). These three subsamples were then made into one representative sample. The collected soil samples were stored in polythene bags and labelled apropriately and the coordinates of the sampling locations taken with a Global Positioning System (GPS). This sampling was done during dry and wet seasons for two consecutive years - 2015 and 2016. In all, a total of two hundred and seventy-six (276) samples, consisting of sixty- nine (69) samples each in both dry and wet seasons, were collected throughout the duration of the sampling exercise. Spots with obvious signs of disturbance, such as animal burrowing, engine oil spillage and landfills, construction sites, accidental vehicle deposit sites, burnt materials and/or deposits of any industrial waste were avoided. The samples were then taken to the laboratory for analysis.

\subsection{Soil preparation, digestion and analysis}

The soil samples were air-dried at room temperature to remove moisture. Thereafter, they were disaggregated and sieved using $2 \mathrm{~mm}$ sieve size prior to digestion. The sieved soil samples were, then, packed into bottles and labelled appropriately. $5 \mathrm{~g}$ of the sieved samples were digested by adding $\mathrm{HNO}_{3} /$ Perchloric acid $(2: 1)$ and the mixture was then placed inside a digestor until a colourless fume was observed. It was then removed, filtered and the required volume of $50 \mathrm{ml}$ was made by adding ultra-pure water. The digested samples were kept in clean polyethylene bottles in a refrigerator prior to analysis. Three replicates of the digested samples were then analyzed for the 
following heavy metals: $\mathrm{Cr}, \mathrm{Pb}, \mathrm{Cu}, \mathrm{Zn}, \mathrm{Fe}, \mathrm{Mn}, \mathrm{Ni}$ and Co using Atomic Absorption Spectrophotometer (Buck Scientific AAS, Model 210VGP, Chapman \& Pratt 1961). All the concentrations were recorded in $\mathrm{mg} / \mathrm{kg}$. Accuracy and precision of the analytical procedures were ensured by the analyses of standard reference materials and replicate samples. Blanks were also analyzed, contents of all the elements in the blanks were below the detection limits.

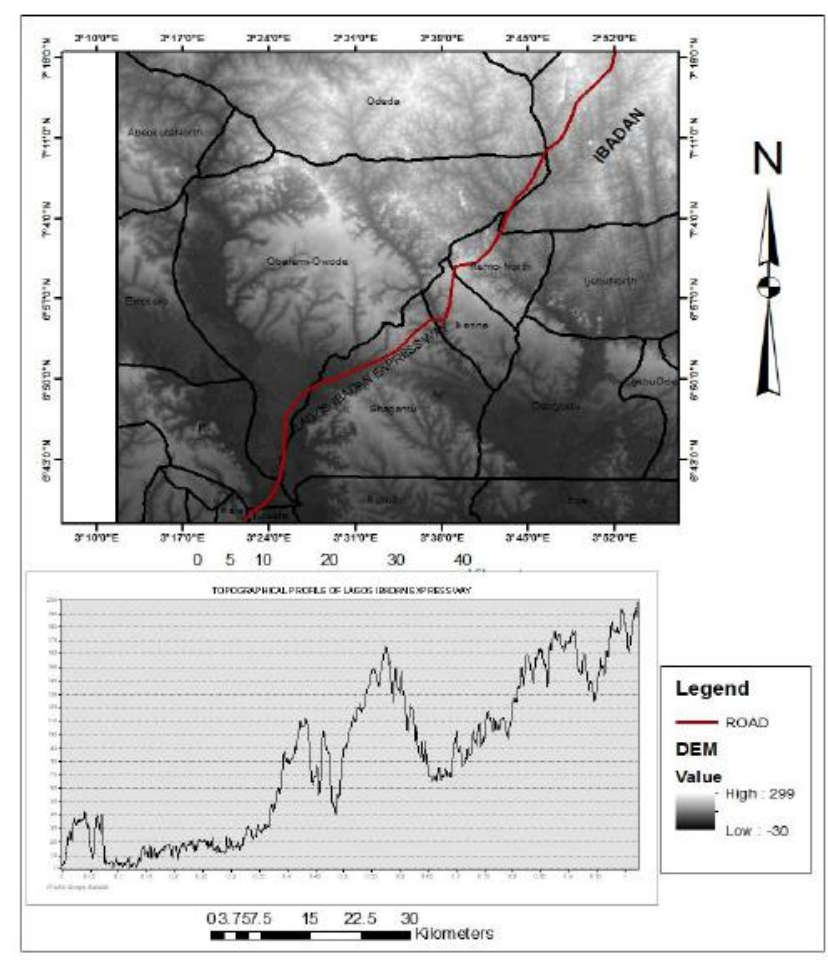

Fig. 1: Topographical Map and Digital Elevation Model (DEM) of Lagos-Ibadan Expressway Profile (Arcgis 10.3.1 Version).

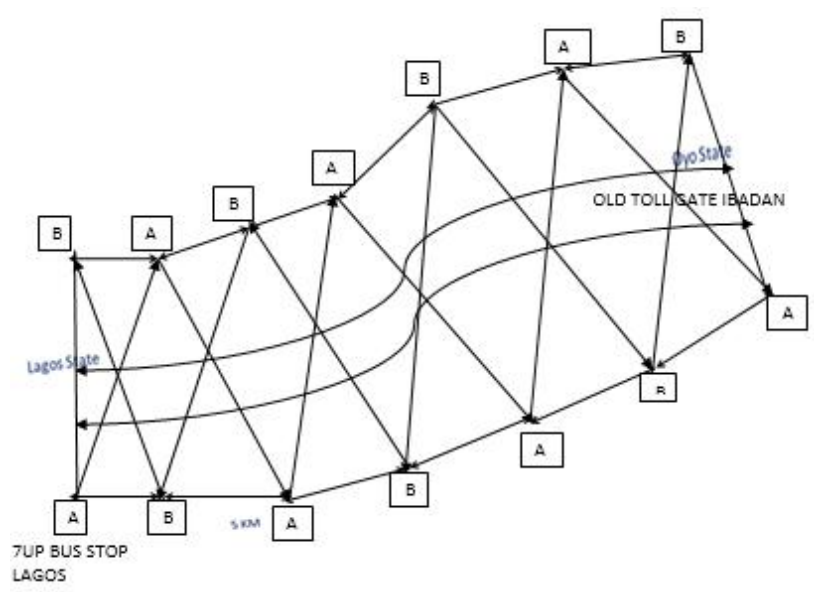

Fig. 2: Systematic zigzag sampling along Lagos-Ibadan Expressway in dry season (January 2015 and January 2016) and in Wet Season (July 2015 and July 2016)

Table 1. Coordinates, Elevations of Sampled Locations along Lagos-Ibadan Expressway

\begin{tabular}{|c|c|c|c|c|}
\hline 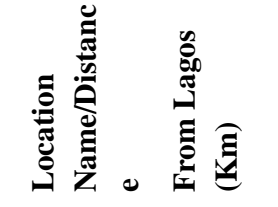 & 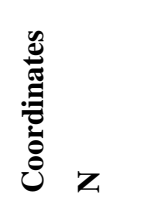 & 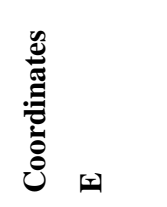 & 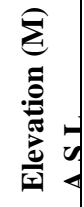 & نْ \\
\hline 7up B/S Lagos (0) & $06^{\circ} 35.976^{\prime}$ & $003^{\circ} 22.710^{\prime}$ & 30 & L1 \\
\hline Secretariat (5) & $06^{\circ} 37.494^{\prime}$ & $003^{\circ} 21.827^{\prime}$ & 18 & $\mathrm{~L} 2$ \\
\hline Opic (10) & $06^{\circ} 39.194^{\prime}$ & $003^{\circ} 23.713^{\prime}$ & 11 & L3 \\
\hline Arepo (15) & $06^{\circ} 41.579^{\prime}$ & $003^{\circ} 24.910^{\prime}$ & 3 & L4 \\
\hline Ile-Epo (20) & $06^{\circ} 44.211^{\prime}$ & $003^{\circ} 25.175^{\prime}$ & 24 & L5 \\
\hline Nasfat/Cntrl (25) & $06^{\circ} 46.921^{\prime}$ & $003^{\circ} 25.451^{\prime}$ & 27 & L6 \\
\hline Redeemed Area (30) & $06^{\circ} 48.921^{\prime}$ & $003^{\circ} 27.103^{\prime}$ & 14 & L7 \\
\hline Ileke Town (35) & $06^{\circ} 49.998^{\prime}$ & $003^{\circ} 29.322^{\prime}$ & 15 & L8 \\
\hline Mowe 1 (40) & $06^{\circ} 51.147^{\prime}$ & $003^{\circ} 31.849^{\prime}$ & 34 & L9 \\
\hline Mowe 2 (45) & $06^{\circ} 52.483^{\prime}$ & $003^{\circ} 34.352^{\prime}$ & 91 & L10 \\
\hline Mallo Fuel (50) & $06^{\circ} 54.146^{\prime}$ & $003^{\circ} 35.881^{\prime}$ & 68 & L11 \\
\hline Ajanla Farm (55) & $06^{\circ} 55.140^{\prime}$ & $003^{\circ} 38.174^{\prime}$ & 58 & L12 \\
\hline Trailer Park (60) & $06^{\circ} 59.878^{\prime}$ & $003^{\circ} 39.106^{\prime}$ & 106 & L13 \\
\hline General Park (65) & $07^{\circ} 00.103^{\prime}$ & $003^{\circ} 40.653^{\prime}$ & 142 & L14 \\
\hline Max Fuel (70) & $07^{\circ} 01.958^{\prime}$ & $003^{\circ} 42.362^{\prime}$ & 85 & L15 \\
\hline Quarry Jnctn (75) & $07^{\circ} 04.321^{\prime}$ & $003^{\circ} 43.249^{\prime}$ & 61 & L16 \\
\hline Stark Fuel (80) & $07^{\circ} 06.450^{\prime}$ & $003^{\circ} 44.722^{\prime}$ & 92 & L17 \\
\hline Namy Sch Area (85) & $07^{\circ} 08.716^{\prime}$ & $003^{\circ} 45.884^{\prime}$ & 104 & L18 \\
\hline Dominon (90) & $07^{\circ} 10.770^{\prime}$ & $003^{\circ} 47.553^{\prime}$ & 126 & L19 \\
\hline M/Mariana H (95) & $07^{\circ} 13.950^{\prime}$ & $003^{\circ} 48.812^{\prime}$ & 153 & L20 \\
\hline Aramed (100) & $07^{\circ} 15.240^{\prime}$ & $003^{\circ} 50.076^{\prime}$ & 145 & L21 \\
\hline Underb Guru (105) & $07^{\circ} 17.135^{\prime}$ & $003^{\circ} 51.768^{\prime}$ & 132 & L22 \\
\hline Toll Gate Ib (110) & $07^{\circ} 19.647^{\prime}$ & $003^{\circ} 52.528^{\prime}$ & 170 & L23 \\
\hline
\end{tabular}

$\mathrm{N}=$ Northings, $\mathrm{E}=$ Eastings, a.s.l = above sea level 


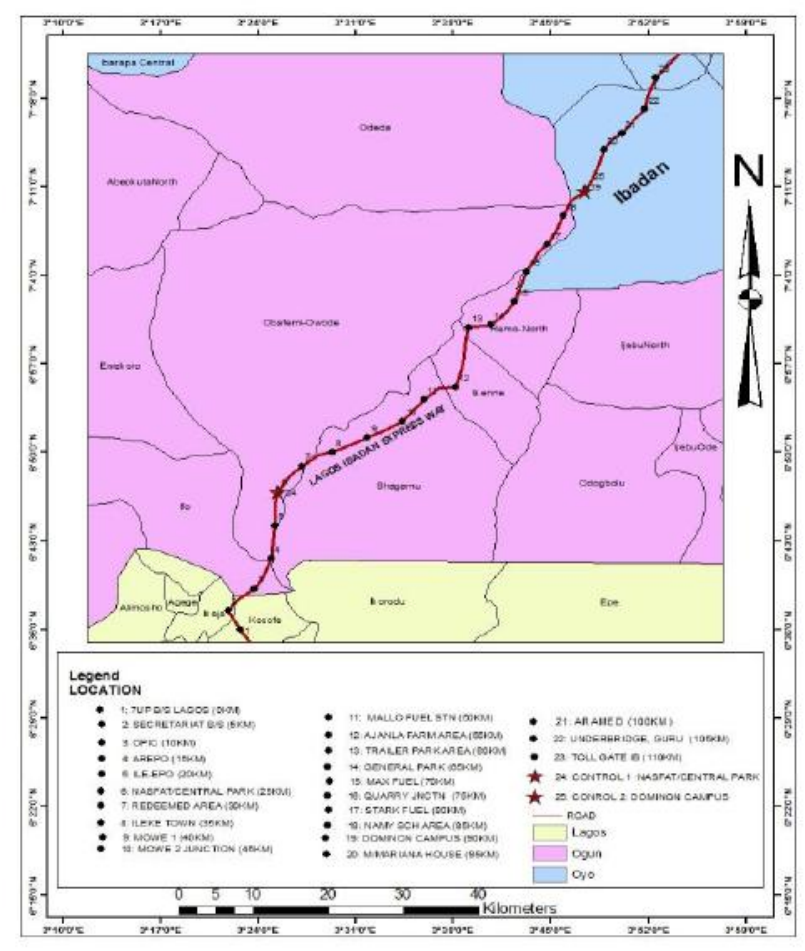

Fig. 3: Itinerary followed During Sample Collection along Lagos-Ibadan Expressway (ArcGIS 10.3.1 Version)

\subsection{Data analysis and assessment of heavy metal pollution}

The geochemical data from the laboratory were then subjected to statistical analyses using the SAS Statistical software 2014 version. Parameters evaluated are mean and standard deviation of the heavy metal concentrations at 5 $\mathrm{m}, 15 \mathrm{~m}$ and $25 \mathrm{~m}$ of each sampling point along the road from Lagos to Ibadan using Duncan's Multiple Range Test. In order to assess the pollution level of the soil, Index of geo-accumulation $\left(I_{\text {geo }}\right)$, Single Ecological Risk Index $(E i)$ and Potential Ecological Risk Index (PERI) were computed using Excel ${ }^{\mathrm{TM}}$ Software 2007 version

\subsubsection{Index of geo-accumulation $\left(I_{\mathrm{geo}}\right)$}

Index of geo-accumulation ( $\left.I_{\text {geo }}\right)$ (Muller, 1981) was calculated using the formula below:

$I_{\text {geo }}=\log _{2}\left(\mathrm{C}_{\mathrm{m}} / 1.5 * \mathrm{~B}_{\mathrm{m}}\right)$

Equation 1

Where

$\mathrm{C}_{\mathrm{m}}=$ Measured concentration of the examined metal in soil samples; and

$\mathrm{B}_{\mathrm{m}}=$ Geochemical background reference value of the same metal.
The background reference adopted in this study was based on the world soil average abundance of metals by Levinson (1974). The constant 1.5 is the background matrix correction factor due to the lithogenic effects. The geo-accumulation values were interpreted using the $I_{g e o}$ classification shown in Table 2

Table 2. Classification of Geo-accumulation Index ( $\left.I_{g e o}\right)$ (After Muller, 1981)

\begin{tabular}{lll}
\hline Index & Value & Degree of Contamination \\
\hline$I_{\text {geo }}$ & $I_{\text {geo }} \leq 0$ & Uncontaminated \\
& $0<I_{\text {geo }} \leq 1$ & $\begin{array}{l}\text { Uncontaminated to moderately } \\
\text { contaminated }\end{array}$ \\
& & Moderately contaminated \\
& $2<I_{\text {geo }} \leq 2$ & Moderately to strongly \\
& & contaminated \\
& $3<I_{g e o} \leq 4$ & Strongly contaminated \\
$4<I_{g e o} \leq 5$ & Strongly to extremely contaminated \\
& $I_{g e o} \geq 5$ & Extremely contaminated \\
\hline
\end{tabular}

\subsubsection{Single Ecological Risk Index (Ei)}

Single Ecological Risk Index (Ei), of a contaminant in an area, was calculated using this formula:

$E_{i}=\mathrm{T}_{i} * \mathrm{CF}_{i}$

Equation 2

Where

$E_{i}=$ Single Ecological Risk Index, $\mathrm{T}_{i}=$ Toxic Response Factor for a given metal, $\mathrm{CF}_{i}=$ Contamination Factor $(\mathrm{CF})$ for the same metal.

Prior to the computation of $E_{i}, \mathrm{CF}_{i}$ was first computed using the formula;

$\mathrm{CF}_{i}=\mathrm{C}_{\mathrm{m}} / \mathrm{B}_{\mathrm{m}}$

Equation 3

Where

$\mathrm{C}_{\mathrm{m}}=$ Measured concentration of the examined metal in soil samples; and

$\mathrm{B}_{\mathrm{m}}=$ Geochemical background reference value of the same metal

The background reference in this study was based on the world soil average abundance of metals by Levinson (1974). The Ecological Risk Index values were interpreted using the classification by Hakanson (1980) (Table 3)

\subsubsection{Potential Ecological Risk Index (PERI)}

Potential Ecological Risk Index (PERI) was computed using this formula:

PERI $(\mathrm{RI})=\Sigma E_{i}$

Equation 4

Where 
$\Sigma=$ summation, $E_{i}=$ Single Ecological Risk Index.

Both the Single Ecological Risk Index $\left(E_{i}\right)$ and Potential Ecological Risk Index (PERI) values were interpreted using the classification in Table 3 .

Table 3. Ecological Risk Index (Hakanson 1980)

\begin{tabular}{lllll}
\hline$E_{i}$ & Pollution Degree & RI & Risk Level & Risk Degree \\
\hline$E_{i}<30$ & Low & RI $<40$ & $\mathrm{~A}$ & Low \\
$30 \leq E_{i}<60$ & Medium & $40 \leq \mathrm{RI}<80$ & $\mathrm{~B}$ & Medium \\
$60 \leq E_{i}<120$ & Strong & $80 \leq \mathrm{RI}<160$ & $\mathrm{C}$ & Strong \\
$120 \leq E_{i}<240$ & Very strong & $160 \leq \mathrm{RI}<320$ & $\mathrm{D}$ & Very strong \\
$E_{i} \geq 240$ & Extremely strong & $\mathrm{RI} \geq 320$ & - & - \\
\hline
\end{tabular}

\section{RESULTS AND DISCUSSION}

3.1 Heavy metal concentrations in sampled soil collected during dry and set seasons

The results of the mean heavy metal concentrations in soil samples collected during dry and wet seasons at $5 \mathrm{~m}, 15 \mathrm{~m}$ and $25 \mathrm{~m}$ away from the edge of the road are presented in Tables $4 \mathrm{a}$ and $4 \mathrm{~b}$. The tables revealed that the mean concentrations of the analyzed heavy metals obtained at a distance of $5 \mathrm{~m}$ away from the edge of the road, during both dry and wet seasons, were significantly higher $(\mathrm{P}>0.05)$ than all the other mean concentrations obtained at $15 \mathrm{~m}$ and $25 \mathrm{~m}$ away from the edge of the road. The mean concentrations of the heavy metals in the soil were in the order $\mathrm{Fe}>\mathrm{Mn}>\mathrm{Zn}>\mathrm{Pb}>\mathrm{Cu}>\mathrm{Cr}>\mathrm{Co}>\mathrm{Ni}$. Metals such as $\mathrm{Fe}, \mathrm{Mn}, \mathrm{Pb}$ and $\mathrm{Zn}$ showed considerable elevated concentrations in the soil.

When the results obtained from this study were compared with that of HSE - ENV (2004), the range of $\mathrm{Cu}$ values, for example, was lower than the range obtained from this study. This result is also true for $\mathrm{Pb}$ as well as $\mathrm{Zn}$ (Table 5). Similarly, the concentrations of the elements from this study were higher than those obtained from Yauri soil, Lagos - Badagry road as well as Osogbo area. For example, the range of concentration values from Yauri soil, Lagos-Badagry road and Osogbo area were 0.91 23.72( ${\left.\mathrm{mg} . \mathrm{kg}^{-1}\right),}^{-1} .99-20.63\left(\mathrm{mg} . \mathrm{kg}^{-1}\right)$ and $27.69-$ $21.19\left(\mathrm{mg} \cdot \mathrm{kg}^{-1}\right)$ respectively for $\mathrm{Cu}$. These values were lower than the $1.05-97.43\left(\mathrm{mg} \cdot \mathrm{kg}^{-1}\right)$ range obtained from this study (Table 6). Table 7 revealed that the results obtained from this study were very similar to those obtained in India and Ethiopia.

3.2 Index of Geo-Accumulation $\left(I_{\mathrm{geo}}\right)$ of Sampled Soil during Dry and Wet Seasons
The Index of geo-accumulation $\left(I_{g e 0}\right)$ for soil samples collected during the dry season is as shown in Fig. 4. A

critical study of the table revealed that Fe had the highest $I_{g e o}$ values while $\mathrm{Ni}$ and Co had the lowest. The $I_{g e o}$ values for $\mathrm{Fe}$ obtained at distances $5 \mathrm{~m}, 15 \mathrm{~m}$ and $25 \mathrm{~m}$ from the edge of the ranged from $28.71-28.88$ with the highest value obtained at a distance of $5 \mathrm{~m}$ away from the edge of the road. Co, on the other hand, had $I_{g e o}$ values of 1.71 , 0.89 and 0.25 at $5 \mathrm{~m}, 15 \mathrm{~m}$ and $25 \mathrm{~m}$ respectively away from the edge of the road. A similar trend was observed for the $I_{g e o}$ values for sampled soil in the raining season, Fe had the highest $I_{g e o}$ values, while $\mathrm{Ni}$ and $\mathrm{Co}$ had the lowest values (Fig. 5). The $I_{g e o}$ values for the elements are in the order $\mathrm{Fe}>\mathrm{Mn}>\mathrm{Zn}>\mathrm{Pb}>\mathrm{Cr}>\mathrm{Cu}>\mathrm{Co}>\mathrm{Ni}$. For all the analyzed elements, the $I_{g e o}$ values reduces with distance away from the edge of the road.

3.3 Single Ecological Risk Index $\left(E_{i}\right)$ and Potential Ecological Risk Index (PERI) of Sampled Soil during dry and wet Seasons from the Edge of the Road

The Single Ecological Risk Index $\left(E_{i}\right)$ for a single element and Potential Ecological Risk Index (PERI) of sampled soil during dry season for the study are shown on Table 8. These $E_{i}$ values decrease as the distance from the edge of the road increases. The table revealed that elevated values of $E_{i}$ were obtained for $\mathrm{Cu}$ while the $E_{i}$ values for $\mathrm{Cr}, \mathrm{Mn}$, $\mathrm{Ni}$ and $\mathrm{Co}$ were very low. The range of Ei of the heavy metals are 0.11-0.34 for $\mathrm{Cr}, 4.59-13.54$ for $\mathrm{Pb}, 28.32$ 45.71 for $\mathrm{Cu}, 1.42-1.99$ for $\mathrm{Zn}, 0.21-0.24$ for $\mathrm{Mn}, 0.002-$ .007 for $\mathrm{Ni}$ and $0.009-0.023$ for Co. In terms of the total Single Ecological Risk Indices $(\Sigma E i)$ of the analyzed heavy metals, $\Sigma E i$ is in the order $\mathrm{Cu}>\mathrm{Pb}>\mathrm{Zn}>\mathrm{Mn}=\mathrm{Cr}>\mathrm{Co}>$ $\mathrm{Ni}$. Therefore, $\mathrm{Cu}$ was the key influencing factor causing potential ecological risk. 
International Journal of Environment, Agriculture and Biotechnology, 5(6)

Nov-Dec, 2020 / Available: https://ijeab.com/

Table 4a. Heavy Metal Mean Concentrations in Sampled Soil Collected during Dry and Wet Seasons from the Edge of the Road

\begin{tabular}{|c|c|c|c|c|c|c|c|c|}
\hline \multirow[t]{4}{*}{ DST } & \multicolumn{2}{|c|}{$\mathrm{Cr}$} & \multicolumn{2}{|c|}{$\mathrm{Pb}$} & \multicolumn{2}{|c|}{$\mathrm{Cu}$} & \multicolumn{2}{|c|}{$\mathrm{Zn}$} \\
\hline & \multicolumn{2}{|c|}{ mg.kg ${ }^{-1}$} & \multicolumn{2}{|c|}{$\mathrm{mg} \cdot \mathrm{kg}^{-1}$} & \multicolumn{2}{|c|}{ mg.kg } & \multicolumn{2}{|c|}{ mg.kg ${ }^{-1}$} \\
\hline & Dry & Wet & Dry & Wet & Dry & Wet & Dry & Wet \\
\hline & Season & Season & Season & Season & Season & Season & Season & Season \\
\hline $5 \mathrm{~m}$ & $15.24 \pm 10.67^{\mathrm{a}}$ & $10.27 \pm 8.48^{\mathrm{a}}$ & $54.17 \pm 51.06^{\mathrm{a}}$ & $84.76 \pm 47.00^{\mathrm{a}}$ & $41.14 \pm 30.20^{\mathrm{a}}$ & $31.72 \pm 26.40^{\mathrm{a}}$ & $189.48 \pm 166.88^{\mathrm{a}}$ & $158.65 \pm 157.52^{\mathrm{a}}$ \\
\hline $15 \mathrm{~m}$ & $9.75 \pm 6.17^{\mathrm{b}}$ & $6.94 \pm 4.73^{b}$ & $34.75 \pm 32.88^{b}$ & $29.96 \pm 29.79^{b}$ & $31.59 \pm 26.24^{b}$ & $26.03 \pm 23.44^{\mathrm{b}}$ & $153.85 \pm 140.82^{b}$ & $139.32 \pm 133.48^{b}$ \\
\hline $25 \mathrm{~m}$ & $4.92 \pm 2.64^{\mathrm{c}}$ & $3.42 \pm 2.09^{c}$ & $18.34 \pm 19.53^{c}$ & $15.72 \pm 18.11^{\mathrm{c}}$ & $25.49 \pm 23.73^{c}$ & $21.99 \pm 22.44^{c}$ & $134.58 \pm 130.65^{\mathrm{c}}$ & $129.44 \pm 128.13^{\mathrm{c}}$ \\
\hline
\end{tabular}

* mean on the same column followed by the same letter are not significantly different at $\mathrm{P}<0.05$. (Duncan's Multiple Range Test). DST $=$ Distance

Table 4b. Heavy Metal Mean Concentrations in Sampled Soil Collected during Dry and Wet Seasons from the Edge of the Road

\begin{tabular}{|c|c|c|c|c|c|c|c|c|}
\hline \multirow[t]{4}{*}{$\overline{\mathrm{DST}}$} & \multicolumn{2}{|c|}{$\mathrm{Fe}$} & \multicolumn{2}{|c|}{$\mathrm{Mn}$} & \multicolumn{2}{|c|}{$\mathrm{Ni}$} & \multicolumn{2}{|c|}{$\mathrm{Co}$} \\
\hline & \multicolumn{2}{|c|}{$\mathrm{mg} \cdot \mathrm{kg}^{-1}$} & \multicolumn{2}{|c|}{$\mathrm{mg} \cdot \mathrm{kg}^{-1}$} & \multicolumn{2}{|c|}{$\mathrm{mg} \cdot \mathrm{kg}^{-1}$} & \multicolumn{2}{|c|}{$\mathrm{mg} \cdot \mathrm{kg}^{-1}$} \\
\hline & Dry & Wet & Dry & Wet & Dry Season & Wet Season & Dry Season & Wet Season \\
\hline & Season & Season & Season & Season & & & & \\
\hline $5 \mathrm{~m}$ & $15746.71 \pm 2780.15 \mathrm{a}$ & $13212.61 \pm 2732.31^{\mathrm{a}}$ & $200.08 \pm 50.46 a$ & $175.03 \pm 42.48^{\mathrm{b}}$ & $0.09 \pm 0.13 \mathrm{a}$ & $0.05 \pm 0.08^{\mathrm{a}}$ & $0.25 \pm 0.20^{\mathrm{a}}$ & $0.17 \pm 0.15^{\mathrm{a}}$ \\
\hline $15 \mathrm{~m}$ & $14319.42 \pm 2238.08 b$ & $13020.96 \pm 2310.04^{\mathrm{ab}}$ & $187.82 \pm 48.34 b$ & $174.43 \pm 47.88^{\mathrm{ab}}$ & $0.04 \pm 0.07 \mathrm{~b}$ & $0.04 \pm 0.06^{\mathrm{b}}$ & $0.14 \pm 0.14^{b}$ & $0.11 \pm 0.09^{b}$ \\
\hline $25 \mathrm{~m}$ & $13975.91 \pm 2622.84 \mathrm{c}$ & $13129.91 \pm 2569.51^{\mathrm{b}}$ & $181.74 \pm 48.55 \mathrm{c}$ & $176.79 \pm 48.02^{\mathrm{a}}$ & $0.02 \pm 0.07 \mathrm{c}$ & $0.03 \pm 0.05^{\mathrm{c}}$ & $0.09 \pm 0.14^{\mathrm{c}}$ & $0.09 \pm 0.11^{\mathrm{c}}$ \\
\hline
\end{tabular}

*mean on the same column followed by the same letter are not significantly different at $\mathrm{P}<0.05$. (Duncan's Multiple Range Test). DST $=$ Distance. 
International Journal of Environment, Agriculture and Biotechnology, 5(6)

Nov-Dec, 2020 / Available: https://ijeab.com/

Table 5. Comparison of Acceptable Range offew Heavy Metals in Some Studies with the Heavy Metals in Sampled Soil in the Present Study

${ }^{\mathrm{a}} \mathrm{HSE}-\mathrm{ENV}(2004)$

\begin{tabular}{|c|c|c|c|c|}
\hline Metals $\left(\mathrm{mg} \mathrm{kg}^{-1}\right)$ & \multicolumn{2}{|c|}{ Acceptable range $^{\mathrm{a}}$} & \multicolumn{2}{|c|}{ Observed range from this study } \\
\hline $\mathrm{Cu}$ & \multicolumn{2}{|c|}{$5-50$} & \multicolumn{2}{|l|}{$1.05-97.43$} \\
\hline $\mathrm{Pb}$ & \multicolumn{2}{|c|}{$5-50$} & \multicolumn{2}{|l|}{$1.85-130.96$} \\
\hline $\mathrm{Zn}$ & \multicolumn{2}{|c|}{$10-120$} & \multicolumn{2}{|l|}{$5.72-558.03$} \\
\hline \multicolumn{5}{|c|}{$\begin{array}{l}\text { Table 6. Comparison of a few Heavy Metals Concentration in Sampled Soil in the Present Study with Similar Studies within } \\
\text { Nigeria }\end{array}$} \\
\hline \multicolumn{5}{|l|}{$\begin{array}{l}\text { metals } \\
\left(\mathrm{mg} \cdot \mathrm{kg}^{-1}\right)\end{array}$} \\
\hline $\mathrm{Cu}$ & $1.05-97.43$ & $0.91-23.72$ & $5.99-20.63$ & $27.69-21.19$ \\
\hline $\mathrm{Pb}$ & $1.85-130.96$ & $35.9-484.9$ & $0.25-4.24$ & $92.07-68.74$ \\
\hline $\mathrm{Zn}$ & $5.72-558.03$ & $79.6-202.4$ & NA & $56.27-42.45$ \\
\hline
\end{tabular}

${ }^{\mathrm{a}}$ Yahaya et al., (2010); ${ }^{\mathrm{b}}$ Adeniyi \& Owoade (2010); ${ }^{\mathrm{c} F a k a y o d e} \&$ Olu-Owolabi (2003); NA: Not applicable

Table 7. Comparison of a few Heavy Metals concentration in Sampled Soil in the Present Study with Similar Studies in the World

\begin{tabular}{|c|c|c|c|c|c|c|c|}
\hline $\begin{array}{l}\text { Metals } \\
\mathrm{mg} \mathrm{kg}^{-1}\end{array}$ & This Study & $\begin{array}{l}{ }^{\text {a Study in }} \\
\text { U.S.A }\end{array}$ & $\begin{array}{l}{ }^{\text {bStudy in }} \\
\text { China }\end{array}$ & $\begin{array}{l}{ }^{\mathrm{c} S t u d y} \text { in } \\
\text { Poland }\end{array}$ & $\begin{array}{l}{ }^{\mathrm{d}} \text { Study in } \\
\text { India }\end{array}$ & $\begin{array}{l}{ }^{\mathrm{e}} \text { Study in } \\
\text { Ethiopia }\end{array}$ & $\begin{array}{l}{ }^{\mathrm{f}} \mathrm{EU} \quad \mathrm{Reg} \\
\text { Standard }\end{array}$ \\
\hline $\mathrm{Cu}$ & $2.67-97.43$ & $2.86-101$ & $7.26-55.1$ & $2.0-18.0$ & $5.34-198.23$ & $23.7-93.0$ & $50-114$ \\
\hline $\mathrm{Pb}$ & $3.64-130.96$ & $4.62-55.4$ & $9.95-56.0$ & $7.1-50.1$ & ND - 623.95 & $20.3-325.4$ & $90-300$ \\
\hline $\mathrm{Mn}$ & $113-271.62$ & $43-2532$ & $134-1740$ & $83-1122$ & NA & NA & 1500 \\
\hline $\mathrm{Ni}$ & $0.003-0.24$ & $2.44-69.4$ & $7.73-70.9$ & $2.0-27.0$ & $343-1409$ & $47.3-200.6$ & 50 \\
\hline
\end{tabular}

Source; ${ }^{a}$ Yahaya et al., (2010); ${ }^{\mathrm{b}}$ Shacklette \& Boerngen (1984); ${ }^{\mathrm{c} B r a d f o r d ~}$ et al., (1996); ${ }^{\mathrm{d} D u d k a}$ (1992); ${ }^{\mathrm{e}}$ Abida et al., (2009) and ${ }^{\mathrm{f}}$ Melaku et al., (2005). ND= Not Detected; NA =Not Available 


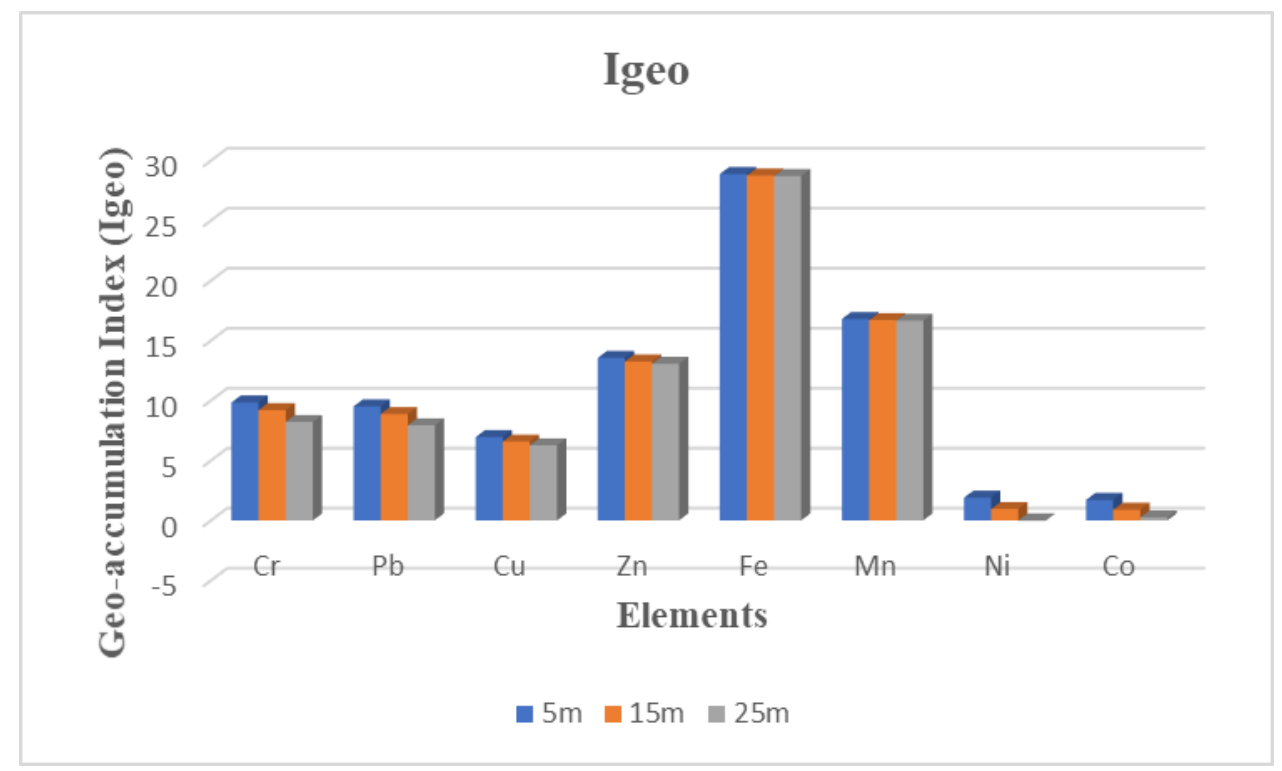

Fig. 4: Index of Geo-accumulation for sampled soil during dry season from the edge of the road inwards

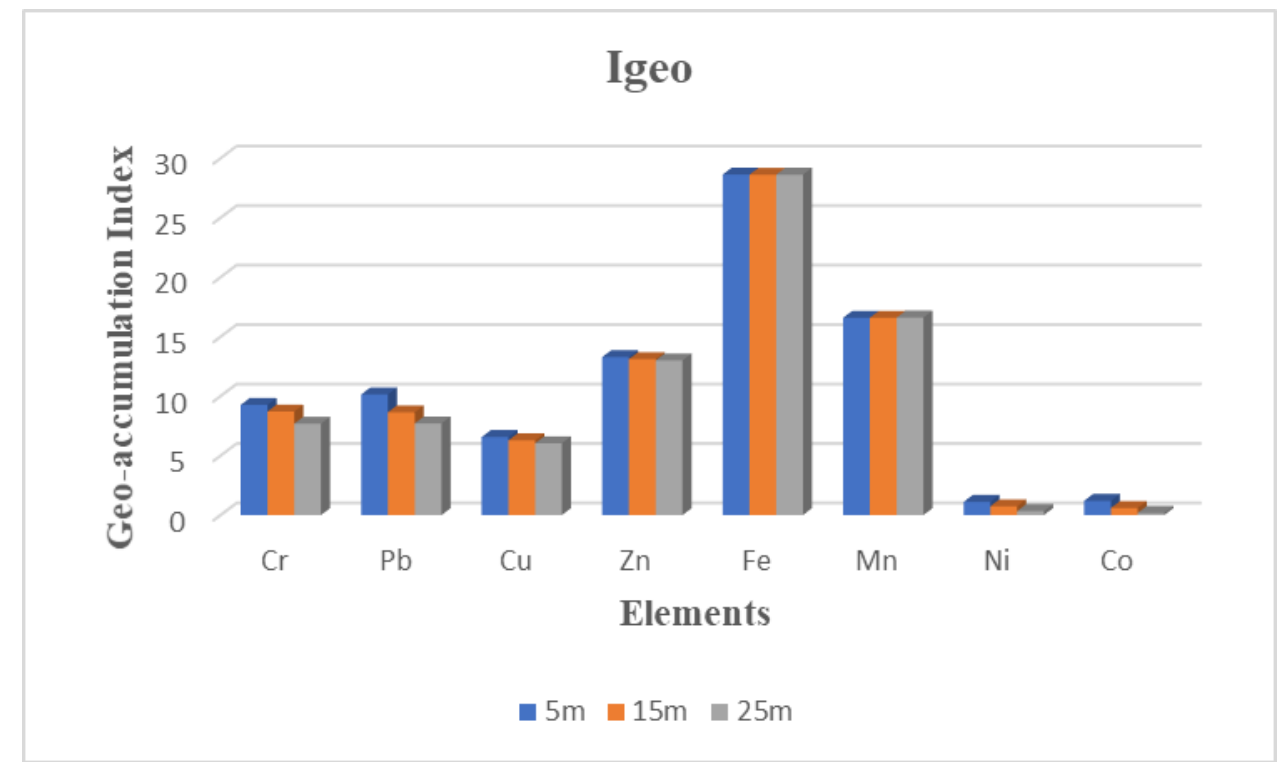

Fig. 5: Index of Geo-accumulation for sampled soil during wet season from the edge of the road inwards

Similar trends were observed for both $E i$ and PERI values for the sampled soil during wet season. Both the $E i$ and PERI values for the analyzed elements reduce with increasing distance away from the edge of the road. For example, while the PERI values was 58.77 at $5 \mathrm{~m}$, it reduced to 38.45 and 30.15 at $15 \mathrm{~m}$ and $25 \mathrm{~m}$ respectively. The range of Ei of the heavy metals are $0.08-0.23(\mathrm{Cr})$, 3.93-21.19(Pb), 24.44-35.25(Cu), 1.36-1.67( $\mathrm{Zn})$, $0.21(\mathrm{Mn}), 0.002-.004(\mathrm{Ni})$ and $0.0085-0.0173(\mathrm{Co})$. In terms of the total Single Ecological Risk Indices $(\Sigma E i)$ of the analyzed heavy metals, $\Sigma E i$ is in the order $\mathrm{Cu}>\mathrm{Pb}>\mathrm{Zn}>$ $\mathrm{Mn}>\mathrm{Cr}>\mathrm{Co}>\mathrm{Ni}$ (Table 9). Therefore, $\mathrm{Cu}$ was the key influencing factor causing potential ecological risk.

The RI for the soil ranged between 34.86 - 62.05 and 30.15 -58.77 for the soils in dry and wet seasons respectively. 
International Journal of Environment, Agriculture and Biotechnology, 5(6)

Nov-Dec, 2020 / Available: https://ijeab.com/

Table 8. Single Ecological Risk Index $\left(E_{i}\right)$ and Potential Ecological Risk Index (PERI) for Sampled Soil during Dry Season from edge of the Road

\begin{tabular}{lllllllll}
\hline DIST & $E i$ & & & & & & \multicolumn{2}{c}{ PERI } \\
\hline \multirow{2}{*}{$5 \mathrm{~m}$} & $\mathrm{Cr}$ & $\mathrm{Pb}$ & $\mathrm{Cu}$ & $\mathrm{Zn}$ & $\mathrm{Mn}$ & $\mathrm{Ni}$ & $\mathrm{Co}$ & \\
$15 \mathrm{~m}$ & 0.34 & 13.54 & 45.71 & 1.99 & 0.24 & 0.007 & 0.023 & 62.05 \\
$25 \mathrm{~m}$ & 0.22 & 8.69 & 35.10 & 1.62 & 0.22 & 0.003 & 0.014 & 46.07 \\
$\mathrm{PERI}=\Sigma E i$ & 0.11 & 4.59 & 28.32 & 1.42 & 0.21 & 0.002 & 0.009 & 34.86 \\
\hline
\end{tabular}

Table 9. Single Ecological Risk Index $\left(E_{i}\right)$ and Potential Ecological Risk Index (PERI) for Sampled Soil during Wet Season from edge of the Road

\begin{tabular}{lcccccccc}
\hline DIST & $\mathrm{E}_{\mathrm{i}}$ & \multicolumn{2}{c}{} & & \multicolumn{3}{c}{ PERI } \\
& $\mathrm{Cr}$ & $\mathrm{Pb}$ & $\mathrm{Cu}$ & $\mathrm{Zn}$ & $\mathrm{Mn}$ & $\mathrm{Ni}$ & $\mathrm{Co}$ & \\
\hline $5 \mathrm{~m}$ & 0.23 & 21.19 & 35.25 & 1.67 & 0.21 & 0.004 & 0.0173 & 58.77 \\
$15 \mathrm{~m}$ & 0.15 & 7.49 & 28.92 & 1.47 & 0.21 & 0.003 & 0.0114 & 38.45 \\
$25 \mathrm{~m}$ & 0.08 & 3.93 & 24.44 & 1.36 & 0.21 & 0.002 & 0.0085 & 30.15 \\
$\mathrm{PERI}=\Sigma \mathrm{E}_{\mathrm{i}}$ & 0.46 & 32.61 & 88.61 & 4.50 & 0.62 & 0.008 & 0.0371 & 127.37 \\
\hline
\end{tabular}

\section{DISCUSSION}

The results of the heavy metal concentrations for sampled soil during dry and wet seasons at $5 \mathrm{~m}, 15 \mathrm{~m}$, and $25 \mathrm{~m}$ from the edge of the road revealed that the mean concentrations of heavy metals reduce as the distance increases away from the edge of the road. This is also in agreement with Mohammed \& Folorunsho (2015) that the closer the soil is to the road, the more likely it will be polluted or contaminated by vehicular/human activities. Concentrations of heavy metals $(\mathrm{Cr}, \mathrm{Pb}, \mathrm{Cu}, \mathrm{Zn}, \mathrm{Fe}, \mathrm{Mn}$, $\mathrm{Ni}, \mathrm{Co})$ in soil were higher in dry season than in wet season at the same distance away from the road. These could probably be due to the fact the elements which were enriched at the top may be depleted/leached at the surface of the soil by rains (Ndiokwere, 1984). Furthermore, erosion, topography, vegetation cover, temperature, soil type and other human activities may be other factors that could add to or reduce the concentrations of these metals in soil in some of the locations along the study area and in general.

However, $\mathrm{Pb}$ concentration of $84.76 \mathrm{mg} / \mathrm{kg}$ was found to be highest at $5 \mathrm{~m}$ during wet season when compared with $\mathrm{Pb}$ concentration of $54.17 \mathrm{mg} / \mathrm{kg}$ recorded during dry season at the same distance. This may be as a result of other anthropogenic activities apart from pollution from vehicular emissions.
The reasons for extremity in concentrations of some of these heavy metals (e.g. Fe, Mn and Zn) in the study area may be as a result of the closeness of some locations to parks especially those around Trailer Park, General Park, Toll Gate, and Ibadan. Other places like 7up Bus stop, OPIC and Redeemed Church which are prone to heavy traffic may likely acquire more deposits of some of these heavy metals.

The main pollutant found in sampled soil during dry and wet seasons are $\mathrm{Zn}, \mathrm{Fe}, \mathrm{Cu}, \mathrm{Pb}$ and $\mathrm{Mn}$. All the heavy metals mentioned above are actually associated with lead fuel, fuel burning (either gasoline or diesel), wear out of tires, leakage of oils, corrosion of car metal parts, traffic and other human activities. These are the daily activities experienced in the study area, Lagos - Ibadan expressway. According to Huntzicher et al., (1975); Ndiokwere, (1984) about $75 \%$ of $\mathrm{Pb}$ is emitted from the exhaust of motor vehicles in particulate form and it is also an important component of anti-knock fluid in petrol. Zn could also be present in tyres of motor vehicles.

Also the research work compared heavy metals obtained in the sampled soil with other previous studies in Nigeria. The result from other parts of the country indicated that $\mathrm{Cu}$ range is higher in Lagos-Ibadan Expressway than that of Yauri soil, Lagos - Badagry road and Osogbo area. This should be expected because the volume of traffic experienced in the study area, Lagos-Ibadan expressway, 
is far more than in any other part of the country. This is also applicable to $\mathrm{Zn}$ while $\mathrm{Pb}$ was within the range of what was obtained at Yauri soil (Adeniyi \& Owoade, 2010; Fakayode \& Olu-Owolabi, 2003; Yahaya et al., 2010). Furthermore, the heavy metals concentrations obtained in this study are very similar to those of India and Ethiopia. This may be so because heavy metal emissions from vehicular emissions and other similar human activities are not regulated in most of the developing countries, India and Ethiopia inclusive.

The geo-accumulation index $\left(I_{\mathrm{geo}}\right)$ values for the soil samples were interpreted using Muller (1981) classification. The average $I_{g e o}$ values for the heavy metals (at $5 \mathrm{~m}, 15 \mathrm{~m}$ and $25 \mathrm{~m}$ ) in the soil samples in both dry and wet seasons are generally higher than 6 especially for $\mathrm{Cr}$, $\mathrm{Pb}, \mathrm{Cu}, \mathrm{Zn}, \mathrm{Mn}$ and $\mathrm{Fe}$. This is an indication that the soil along Lagos - Ibadan Expressway are extremely contaminated with respect to these elements. The average $I_{\text {geo }}$ values for both $\mathrm{Co}$ and $\mathrm{Ni}$ ranged between $0-2$ (i.e. $0<I_{g e o} \leq 2$ ) for both wet and dry seasons, indicating that the soils are uncontaminated to moderately contaminated. It also showed that pollution, in most of the study area, is not as a result of geological activities but as a result of vehicular movements and other anthropogenic activities. However, the average $I_{\text {geo }}$ for $\mathrm{Ni}$ showed a negative value, at a distance of $25 \mathrm{~m}$ away from the road, which indicates that the metal is not a pollutant to that environment at that location. Therefore, the source of the metal at this location could probably be from the rocks underlying the area. Furthermore, the $I_{\text {geo }}$ values for soil sampled during dry season were higher than $I_{g e o}$ values for soils collected during wet season in the study area over the same period of time.

Single Potential Ecological Risk Index of metals in the soil was also assessed. During dry season, only $\mathrm{Cu}$ showed the highest risk index of 45.71 at $5 \mathrm{~m}$ from the edge of the road, which reduced to 28.32 at $25 \mathrm{~m}$ from the edge of the road. The total Single Ecological Risk Indices $(\Sigma E i)$ of the analyzed heavy metals, $\Sigma E i$, is in the order $\mathrm{Cu}>\mathrm{Pb}>\mathrm{Zn}>$ $\mathrm{Mn}=\mathrm{Cr}>\mathrm{Co}>\mathrm{Ni}$. Therefore, $\mathrm{Cu}$ was the key influencing factor causing potential ecological risk. The RI at $5 \mathrm{~m}$ (62.05) and $15 \mathrm{~m}$ (46.07) away from the road indicated that the soil potential ecological risk index was level $\mathrm{B}$ corresponding to moderate ecological risk. A similar result was obtained for the $E i$ of the elements during wet season. The total $\Sigma$ Ei being in the order $\mathrm{Cu}>\mathrm{Pb}>\mathrm{Zn}>\mathrm{Mn}=\mathrm{Cr}>$ $\mathrm{Co}>\mathrm{Ni}$ while the $\mathrm{RI}$ values indicated that the soil ecological risk index was medium at a distance of $5 \mathrm{~m}$ away from the road.

\section{CONCLUSION}

There was a general reduction in heavy metal concentrations in the soil samples collected in rainy season when compared with sampled soil in dry season and when moved $5 \mathrm{~m}, 15 \mathrm{~m}$ and $25 \mathrm{~m}$ away from the edge of the road.

Index of geo-accumulation $\left(I_{g e o}\right)$ of sampled soil revealed that contamination ranged from uncontaminated to extreme contamination in the study locations during dry and wet seasons. The $I_{g e o}$ for Ni showed negative values in many sites which is an indication that the metal is not a pollutant from exhaust and the source is probably geogenic. The sampling points $5 \mathrm{~m}$ away from the road exhibited a medium potential ecological risk for $\mathrm{Cu}$.

The research results showed that $\mathrm{Fe}, \mathrm{Mn}, \mathrm{Zn}, \mathrm{Pb}$, $\mathrm{Cu}$ and $\mathrm{Cr}$ are the major heavy metal pollutants in the soil during dry and wet seasons, while $\mathrm{Ni}$ and $\mathrm{Co}$ are the least prevalent. A critical factor that could have contributed significantly to deposition and accumulation of these heavy metals in the soil for both seasons is the volume of traffic along Lagos-Ibadan Expressway which varied from time to time. Constructions, refuse dumps, effluent or release of industrial waste, accident on the highway resulting into spillage of dangerous chemicals into the environment may also have contributed to the deposition of these heavy metals in soil.

The study area, Lagos - Ibadan Expressway, is highly polluted and the major source of pollution is through anthropogenic activities, which are mainly from exhaust emissions from vehicular movement along the expressway over time. The study has also provided some relevant baseline information for accessing the public health risks, which could arise from living, farming, grazing or fish ponds along Lagos-Ibadan Expressway. For the people that have been living along the highway for years it is advisable for such people to go for comprehensive medical test to know their health status as regards the amount of heavy metals present in their body before it is too late.

\section{REFERENCES}

[1] Abida, B., Ramaih, M, Harikrishma, I. K. \& Veena. K. (2009). Analysis of heavy metals concentrations in soils and litchens from various localities of Hosur road, Bangalore, India. E-Journal of Chemistry. 1: 13-22.

[2] Adeniyi, A. A., Owoade, O. J. (2010). Total petroleum hydrocarbons and trace heavy metals in roadside soils along the Lagos Badagry Expressway, Nigeria. Environ. Monit. Assess. 167: $625-630$. 
[3] Akbar, K. F., Hale, W. H., Headley, A. D. \& Athar, M. (2006). Heavy metal contamination of roadside soils of Northern England. Soil and Water Research, 1: 158-163.

[4] Atayese, M. O., Eigbadon, A. I., Oluwa, K. A. \& Adesodun, J. K. (2010). Heavy metal Contamination of Amaranthus grown along major highways in Lagos, Nigeria. African Crop Science; 16(4): 25-235.

[5] Bradford, G. R, Chang, A. C. \& Page, A. L. (1996). Background concentrations of trace and major elements in California soils. Kearney Foundation Special Report, University of California, Riverside, 1-52.

[6] Dolan, L. M. J., Van, B. H. \& Whelan, P. (2006). Towards the sustainable development of modern road ecosystem. In: J. Davenport and J. L. Davenport, editors. The Ecology of Transportation: Managing Mobility for the Environment. Environmental Pollution. Springer, Amsterdam, Netherlands. 10: 275-331.

[7] Dudka, S. (1992). Factor analysis of total element concentrations in surface soils of Poland. Sci. Total Environ. 121: 39-52.

[8] Ezemokwe, D. E., Ichu, C. B., Okoro, J. N. \& Opera, A. I. (2017). Evaluation of heavy metal contamination of soils alongside Awka-Enugu Road, southeastern Nigeria. Asian Journal of Environment and Ecology. 4(1); 1-11, Article no AJEE 34865. ISSN: $2456-690 x$.

[9] Fakayode, S. O. \& Olu-Owolabi, B. I. (2003). Heavy metal contamination of roadside topsoil in Osogbo, Nigeria. Its relationship to traffic density and proximity to highways. Environ. Geol. 44: 150 - 157.

[10] Fosu-Mensah, B. Y., Emmanuel, A., Dzidzo, Y. \& Frank. N. (2017). Heavy metals concentration and distribution in soils and vegetation at Korle Lagoon area in Accra, Ghana. Cogent Environmental Science. 3:1405887.

[11] Håkanson, L. (1980). An ecological risk index for aquatic pollution control - A sedimentological approach. Water Res [Internet]. [cited 2019 Dec 13]; 14(8):975-1001. Available from: https//doi.org/10.1016/0043-1354(80)90143-8.

[12] HSE-ENV (2004). Accompanying guidelines for SPDC EIA process. Data Collection: Vol. 3. HSE-ENV, SPDC, $2004-$ 0002712.

[13] Huntzicker, J. J. Friedlander, S. K. \& Davidson, C. I. (1975). Flow of trace elements through the Los Angeles Basin. Zinc, cadmium and nickel. Environ. Sci. Technol.,9, 448.

[14] Levinson, A. A. (1974). Introduction to exploration geochemistry: Calgary, Applied Publishing Ltd., 612p.

[15] Melaku, S., Wondimu, T., Dams, R. \& Moens, L. (2005). Multi-element analysis of Tinishu Akaki River Sediment, Ethiopia, by ICP-MS after microwave assisted Digestion. Can. J. Anal. Sci. Spec. 50: 1.

[16] Mohammed, S. A. \& Folorunsho, J. O. (2015). Heavy metals concentration in soil and Amaranthus retroflexus grown on irrigated farmlands in the Makera Area, Kaduna, Nigeria. Journal Geography and Regional Planning. 8: 210 $-217$.

[17] Muller, G. (1981). Die schwermetallbelastung der sedimenten des Neckars und seiner
Nebenflusse. Chemiker-Zeitung. 6: 157-164.

[18] Ndiokwere, C. L. (1984). A study of heavy metal pollution from motor vehicle emissions and its effects on roadside soil, vegetation and crops in Nigeria. Environmental Pollution, Series B, 7, 35-42.

[19] Obaje, N. G. (2009). Geology and mineral resources of Nigeria, Lecture notes in Earth sciences. $1^{\text {st }}$ edition. Berlin: Springer-Verlag Berlin; 221p.

[20] Olukanni, D. O. \& Adebiyi, S. A. (2012). Assessment of vehicular pollution of road side soils in Ota Metropolis, Ogun State, Nigeria. International Journal of Civil and Environmental Engineering. 12(4): 40-46.

[21] Omatsola, M. E. \& Adegoke, O. S. (1981). Tectonic evolution and Cretaceous stratigraphy of the Dahomey basin. Journal of Mining and Geology. 18, 130-137.

[22] Poszyler-Adamska, A. \& Czerniak, A. (2007). Biological and chemical indication of Roadside ecotone zones. Journal of Environmental Engineering and Landscape Management. 15 (2): $113-118$.

[23] Shacklette, H. T. \& Boerngen, J. G. (1984). Element concentrations in soils and other surficial materials of the conterminous United States. U.S. Geological Survey Professional Paper. 1270: 105.

[24] Simon, E. A., Vidic, M., Braun, I. \& T’othm'er'esz, B. (2013). Trace element concentrations in soils along urbanization gradients in the city of Wien, Austria. Environmental Science and Pollution Research. 20(2): 917924.

[25] Suzuki, K., Yabuki, T. \& Ono, Y. (2009). Roadside and macronutrient contents of roadside soil and vegetation in Umuahia, Nigeria. Terrest. Aquat. Environ. Toxicol, 5: 3539.

[26] Yahaya, M. I., Ezeh, G. C., Musa, Y. F. \& Mohammed, S. Y. (2010). Analysis of heavy metals concentration in roadsides soil in Yauri, Nigeria. Afr. J. Pure Applied Chem. 4: 22-30. 